\title{
Modeling the Recommendation of Nutrients for Cabbage (Brassica oleracea) Crop
}

\author{
Thaísa Fernanda Oliveira ${ }^{1}$, Leonardo Angelo de Aquino ${ }^{1}$, Maria Elisa Paraguassu Soares ${ }^{1}$, Talita Gabriela Gentil ${ }^{1}$, \\ Flávio Lemes Fernandes ${ }^{1}$, Junia Maria Clemente ${ }^{1} \&$ Marcelo Rodrigues dos Reis ${ }^{1}$ \\ ${ }^{1}$ Crop Production Department, Federal University of Viçosa, Rio Paranaíba, Minas Gerais, Brazil \\ Correspondence: Thaísa Fernanda Oliveira, Crop Production Department, Federal University of Viçosa, campus \\ Rio Paranaíba, km 7-Zona Rural, MG-230, Rodoviário, CEP: 38810-000, Rio Paranaíba, Minas Gerais, Brazil. \\ E-mail: thaisafernanda135@gmail.com
}

Received: February 2, 2019

Accepted: March 4, 2019 Online Published: May 31, 2019

doi:10.5539/jas.v11n7p220

URL: https://doi.org/10.5539/jas.v11n7p220

\begin{abstract}
Cabbage presents high nutrients demand, which requires proposal of recommendation models that are compatible with current productive potential. The objective of this study was to propose a nutritional balance model to recommend nutrients for cabbage. In order to estimate fertilizer recommendation, the system considered the requirement subsystem (REQ), which includes the crop demand and recovery efficiency (RE) of the applied nutrient, and supply subsystem (SUP), which corresponds to the nutrient supply by soil and crop residues. To determine the attributes needed to estimate nutritional demand, values were obtained from literature and from two experiments, one with nitrogen $(\mathrm{N})$ and one with potassium $(\mathrm{K})$. The fertilizer recommendation for $\mathrm{N}, \mathrm{P}$ and $\mathrm{K}$ consisted in the difference between REQ and SUP. For the other nutrients, the system presented only crop export and extraction and not the REQ due to scarcity of data regarding RE. The modeling is a useful tool for recommending fertilization for cabbage and is subject to constant improvements.
\end{abstract}

Keywords: fertilization, mathematical models, nutritional balance, productivity potential

\section{Introduction}

In Brazil, official recommendation of fertilizers such as "Boletim 100" (Raij et al., 1996) and "5a Aproximação" (CFSEMG, 1999) present limitations such as low aimed productivity potential, besides they do not consider demand variations with productivity in a continuous way and differences that may exist among cultivars and cultivation time for a same cultivar. Therefore, fertilizations are quite empiric and performed by farmers that apply fixed doses of nutrients. Doses should consider at least expected productivity, nutrient availability, and soil buffer capacity, in addition to the plant's efficiency to uptake them (Santos et al., 2008; Silva et al., 2009; Singh et al., 2012).

Currently, there are in Brazil nutritional balance systems for several crops, such as pineapple (Silva et al., 2009), soybean (Santos et al., 2008; Kurihara et al., 2013), carrot (Dezordi et al., 2015), melon (Deus et al., 2015), among others. These systems comprise mathematical models that allow estimating the nutrient requirements of the crop according to the expected productivity, as well nutrient supply from soil in response to the results of soil chemical analysis (available nutrients) and crop residues. Therefore, in these models, fertilizers recommendation comprises the difference between crop demand and nutrient supply available in the soil plus mineralization of crop residues.

Among vegetables, brassicas present high nutrients demand due to the high productivity of dry matter in a short period of time. Cabbage is the main commercial species of Brassicaceae and one of the main vegetables grown in Brazil. The nutritional balance system is a tool that may improve the estimation of nutrients need and support fertilizations consistent with the desired productivity of cabbage and soil fertility. The objective of this study was to propose a nutritional balance model to recommend nutrients for cabbage crop.

\section{Material and Methods}

\subsection{Development of the System}

The mathematical models comprised in the fertilizer recommendation system for cabbage were divided into two subsystems: nutrient requirement (REQ) and soil nutrient supply (SUP). The crop demand and recovery 
efficiency (RE) of the applied nutrient were considered to estimate the REQ. The crop demand was calculated based on dry matter content (DMC), coefficient of biological utilization (CUB) of the nutrients and harvest index (HI). RE indicates the percentage of the nutrient applied to the soil that plant recovers (Fageria, 1998). The CUB is an efficiency index that indicates the ability of the plant to convert nutrient uptake into dry matter (Fageria, 1998). The HI represents the mass fraction of dry matter (DM) or nutrient present in the commercial organ of the crop (head in case of cabbage) regarding all DM of the plant.

The SUP considered the nutrient supply by soil and residues from previous crops. The modeling of soil nutrient supply was based on studies available in the literature. Among these, stand out those performed to determine the recovery efficiency of extractors used in the soil analysis and the studies carried out to study the accumulation and dynamics of mineralization and nutrient release by crop residues as observed by Setiyono et al. (2010), and Marcelo et al. (2012).

\subsection{Requirement Subsystem-REQ}

\subsubsection{Determination of Attributes for Modeling Nutritional Demand}

To estimate the attributes required for modeling the nutritional demand of cabbage crop, data were obtained from researches of Aquino et al. (2009), Correa et al. (2013), and Silva (2016). However, the data available in the literature were not enough for modeling the nutritional demand; therefore two more experiments were carried out to complement this database. Both experiments were performed at Universidade Federal de Viçosa (UFV), Campus Rio Paranaíba, Rio Paranaíba-Brazil (Latitude: 19¹1'39" S; Longitude: 46¹4'37" W).

\subsubsection{Experiment 1: Partition of Accumulation of N, P and K in Cabbage Plant}

The experiment was carried out in a greenhouse in the period of May 13, 2016 (seedlings transplant) and August 10, 2016 (harvest), aiming to determine the partition and accumulation of $\mathrm{N}, \mathrm{P}$ and $\mathrm{K}$ in root, stem, head and outer leaves of cabbage plants. Pots with a capacity of $250 \mathrm{dm}^{3}$ were filled with sifted soil, which is classified as Latossolo Vermelho Amarelo with a very clayey texture. Soil analysis showed the following chemical characteristics: $\mathrm{pH}\left(\mathrm{H}_{2} \mathrm{O}\right)=5.7 ; \mathrm{Ca}^{2+}=5.8 ; \mathrm{Mg}^{2+}=1.2 ; \mathrm{Al}^{3+}=0$, expressed in cmolc dm${ }^{-3}, \mathrm{P}=13.4$ (Mehlich-1 Extractor); $\mathrm{S}=14.7 ; \mathrm{K}=46.2$ expressed in $\mathrm{mg} \mathrm{dm}{ }^{-3}$, organic matter $=3.1 \mathrm{~kg} \mathrm{~kg}^{-1}$ and $\mathrm{V}=63 \%$.

Each experimental unit consisted of a polyethylene pot $\left(250 \mathrm{dm}^{3}\right)$, where four plants per pot were cultivated in a total of 16 pots. The cultivar used was Astrus Plus. The management of irrigation and control of pests and diseases was carried out according to the crop necessity.

At 0-20 cm depth of the soil, $0.4 \mathrm{mg} \mathrm{dm}^{-3}$ of $\mathrm{Cu}, 0.5 \mathrm{mg} \mathrm{dm}^{-3}$ of $\mathrm{B}, 100 \mathrm{mg} \mathrm{dm}^{-3}$ of $\mathrm{K}$ and $170 \mathrm{mg} \mathrm{dm}^{-3}$ of N, were applied and incorporated before transplantation. The P application was localized. In four holes, with $10 \mathrm{~cm}$ in diameter and $10 \mathrm{~cm}$ depth, were mixed $8 \mathrm{~g}$ of $\mathrm{P}_{2} \mathrm{O}_{5}$ in soil. After that, the holes were covered where the cabbage seedlings were transplanted. At 40 days after transplantation, it was applied further $50 \mathrm{mg} \mathrm{dm}^{-3}$ of K.

The harvest was performed when compactness (firmness) of heads reached commercial acceptance. In each experimental unit, the four plants were harvested and weighed separately which were partitioned into head, outer leaves, stem and root. The whole root mass of pot was withdrawn and determined the fresh matter (FM) and dry matter (DM). FM was determined at harvest time. The samples were washed to remove the impurities and taken to a forced circulation oven at $70{ }^{\circ} \mathrm{C}$ during $72 \mathrm{~h}$. Later, they were removed and weighed to DM determination. The dried samples were ground in a Willey mill equipped with a $1.27 \mathrm{~mm}$ sieve and taken to the laboratory to determine macronutrient contents (N, P and K), according to the methods described by Silva (2009) The accumulations of nutrients in each part of the plant were calculated by the product between DM and nutrient content in the respective organ of plant. Accumulation of nutrients in percentage was calculated by the accumulated in each part of plant (head, leaf, stem and root) in relation to the total accumulated in whole plant.

From quantification of nutrient partition of each organ, constants were determined to the adjustment of REQ subsystem for $\mathrm{N}, \mathrm{P}$ and $\mathrm{K}$ for modeling, considering the allocation of these nutrients to the stem and root system. The constants were calculated by the ratio between total accumulated in whole plant (head, external leaves, stem and root) and nutrient accumulation in the shoot (head and external leaves) (Table 1). The values of constants were: N-1.095282; P-1.132624; and K-1.112715. It is equivalent to information of 9.53, 13.26 and $11.27 \%$ of the $\mathrm{N}, \mathrm{P}$ and $\mathrm{K}$ extracted by plant allocated in stem plus root system, respectively. 
Table 1. Regression equations fitted for fresh matter (FM) of head and accumulation of $\mathrm{N}, \mathrm{P}$ and $\mathrm{K}$ in head, external leaves, stem and root of cabbage

\begin{tabular}{lll}
\hline Variables & Nutrient accumulation $\left(\mathrm{g} \mathrm{planta}^{-1}\right)$ & Partition of nutrient $(\%)$ \\
\hline N head & 4.436 & 60.1 \\
N external leaves & 2.308 & 31.2 \\
N stem & 0.299 & 4.0 \\
N root & 0.344 & 4.7 \\
\hline P head & 0.682 & 62.3 \\
P external leaves & 0.284 & 26.0 \\
P stem & 0.055 & 5.0 \\
P root & 0.073 & 6.7 \\
\hline K head & 4.744 & 64.6 \\
K external leaves & 1.861 & 25.3 \\
K stem & 0.510 & 6.9 \\
K root & 0.234 & 3.2 \\
\hline
\end{tabular}

\subsubsection{Experiment 2: Doses and Sources of $\mathrm{K}$ in Cabbage}

The experiment was carried out in the field, repeated twice, at different growing seasons (summer and winter), to determine RE of K by cabbage. The seedlings transplanting of summer period was carried out in December 2015 and harvested in February 2016. In winter period, the transplant was in May 2016 and harvested in August 2016. The cultivar of cabbage used was Astrus Plus. Soils presented 106 and $65 \mathrm{mg} \mathrm{dm}^{-3}$ of K available at $0-20 \mathrm{~cm}$ depth in summer and winter growing seasons, respectively. The chemical attributes are presented in Table 2.

Table 2. Soil chemical analysis at 0-20 and 20-40 cm depth in the summer and winter growing seasons

\begin{tabular}{|c|c|c|c|c|c|c|c|c|c|c|c|c|c|}
\hline Growing season & Layer & $\mathrm{pH}^{(1)}$ & P-rem & $\mathrm{P}^{(2)}$ & $\mathrm{K}^{+(2)}$ & $\mathrm{S}^{(3)}$ & $\mathrm{Ca}^{2+(4)}$ & $\mathrm{Mg}^{2+(4)}$ & $\mathrm{Al}^{3+(4)}$ & $\mathrm{H}+\mathrm{Al}^{(5)}$ & O.M. & V & $\mathrm{m}$ \\
\hline & $\mathrm{cm}$ & $\mathrm{H}_{2} \mathrm{O}$ & $\mathrm{mg} \mathrm{L}^{-1}$ & ----- & $\overline{\mathrm{ng} \mathrm{dm}}$ & ב---- & -.--- & --- $\mathrm{cmol}$ & $\mathrm{dm}^{-3}-$ & - & dag $\mathrm{dm}^{-3}$ & $-\overline{c---}$ & ---- \\
\hline \multirow{2}{*}{ Summer } & $0-20$ & 5.5 & 22.1 & 16.9 & 106.0 & 30.0 & 2.8 & 0.7 & 0.14 & 5.1 & 2.0 & 42.5 & 3.6 \\
\hline & $20-40$ & 5.3 & 17.8 & 8.5 & 76.0 & 35.0 & 2.8 & 0.6 & 0.27 & 4.9 & 1.8 & 42.3 & 7.0 \\
\hline \multirow{2}{*}{ Winter } & $0-20$ & 5.7 & 22.4 & 12.8 & 65.0 & 24.0 & 4.4 & 1.0 & 0.00 & 3.6 & 3.1 & 60.7 & 0.0 \\
\hline & $20-40$ & 5.7 & 14.3 & 4.2 & 34.0 & 23.0 & 3.6 & 0.9 & 0.00 & 3.5 & 2.5 & 56.7 & 0.0 \\
\hline
\end{tabular}

Note. $(1)=$ Ratio 1:2.5; (2) = Mehlich 1 extractor; (3) = monocalcium phosphate extractor in acetic acid; (4) = $\mathrm{KCl} 1 \mathrm{~mol} \mathrm{~L}^{-1}$ extractor; (5) calcium acetate extractor $0.5 \mathrm{~mol} \mathrm{~L}-1 / \mathrm{pH} 7.0$.

The treatments consisted of 0, 100, 200, 400 and $800 \mathrm{~kg} \mathrm{ha}^{-1}$ of $\mathrm{K}_{2} \mathrm{O}$ applied as Potassium Chloride (KCl). An additional treatment consisted of Potassium Sulphate $\left(\mathrm{K}_{2} \mathrm{SO}_{4}\right)$ at $200 \mathrm{~kg} \mathrm{ha}^{-1}$ of $\mathrm{K}_{2} \mathrm{O}$. The dose of $200 \mathrm{~kg}$ ha applied as $\mathrm{K}_{2} \mathrm{SO}_{4}$ was tested in order to obtain a comparison between $\mathrm{K}$ sources. Except the control (dose 0 of $\mathrm{K}_{2} \mathrm{O}$ ), the other treatments received $100 \mathrm{~kg} \mathrm{ha}^{-1}$ of $\mathrm{K}_{2} \mathrm{O}$ at seedlings transplant. Therefore, treatment with $100 \mathrm{~kg}$ $\mathrm{ha}^{-1}$ of $\mathrm{K}_{2} \mathrm{O}$ was performed all at transplant. Treatment with $200 \mathrm{~kg} \mathrm{ha}^{-1}$ of $\mathrm{K}_{2} \mathrm{O}$ was splitted with $100 \mathrm{~kg} \mathrm{ha}^{-1}$ of $\mathrm{K}_{2} \mathrm{O}$ at transplant and $100 \mathrm{~kg} \mathrm{ha}^{-1}$ of $\mathrm{K}_{2} \mathrm{O}$ at 10 days after transplant.

The experiment was designed as randomized blocks with four replications. The plots presented four rows with six meters length and the useful were the two central, excluding $60 \mathrm{~cm}$ from edges. The plants were spaced at 38 $\mathrm{cm}$ between rows and plants for both experiments.

The soil preparation consisted of a plowing and two harrowing. Excepting for $\mathrm{K}$, the soil correction acidity and fertilizations were carried out according to soil chemical analysis and crop recommendations. The seedlings were transplanted at 35 days after sowing. Crop treatments, pest control, and conventional sprinkler irrigation were performed according to crop needs. The meteorological data in the region during experiment conduction are shown in Figure 1. 


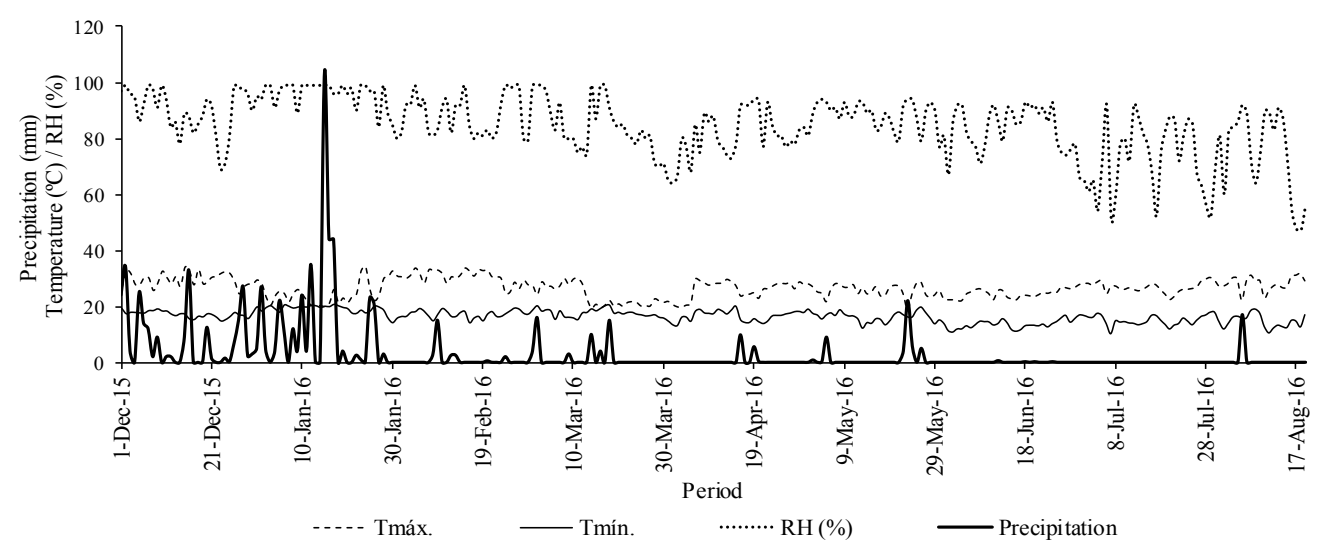

Figure 1. Precipitation, maximum temperature (Tmax), minimum temperature (Tmin.) and relative humidity (RH\%) in Alto Paranaíba region-Brazil, from December 2015 to August 2016

The harvest was performed when heads compactness reached commercial acceptance. Ten uniform plants were harvested from useful plot and separated in heads (commercial part) and external leaves (vegetal remains), that originate the data of productivity and average fresh mass of heads and external leaves.

After weighing, the heads and external leaves were washed, grinded and placed in a forced air oven at $70{ }^{\circ} \mathrm{C}$ until constant weigh in order to determine DM. The K content was determined according to Silva (2009). The K accumulations in each part of plants (head and external leaves) were calculated by the product between DM and $\mathrm{K}$ content for each organ. The total accumulated in the heads and external leaves are nutrients accumulation in the shoot, and the total accumulated only in the heads was the nutrients export.

\subsection{Coefficient of Biological Utilization (CUB) and Nutrient Harvest Index (HI)}

The CUB was calculated by the ratio between dry matter and the quantity of the nutrient accumulated in the plant. The HI was calculated by the ratio between extraction (amount accumulated in the heads and external leaves) and export (quantity accumulated in heads). For this first version of modeling the recommendation, it was used average values obtained in the researches of Aquino et al. (2009), Correa et al. (2013) and Silva (2016) and experiments with K (Subsection 2.2.3) for TMS, CUB and HI (Table 3). It should be noted that there is a range of values, which allows the user a choice depending on their cultivation condition. 
Table 3. Content of dry matter (TMS), coefficient of biological utilization (CUB) and harvest index (HI) of macro and micronutrients in cabbage cultivars

\begin{tabular}{|c|c|c|c|c|c|c|c|c|c|c|c|c|c|c|c|c|c|c|c|c|c|}
\hline \multirow{2}{*}{ Cultivar } & \multirow{2}{*}{ TMS } & \multicolumn{10}{|c|}{ CUB } & \multicolumn{10}{|c|}{$\mathrm{HI}$} \\
\hline & & $\mathrm{N}$ & $\mathrm{P}$ & $\mathrm{K}$ & $\mathrm{Ca}$ & $\mathrm{Mg}$ & $\mathrm{S}$ & $\mathrm{Cu}$ & $\mathrm{Fe}$ & $\mathrm{Mn}$ & $\mathrm{Zn}$ & $\overline{\mathrm{N}}$ & $\mathrm{P}$ & $\mathrm{K}$ & $\mathrm{Ca}$ & $\mathrm{Mg}$ & $S$ & $\mathrm{Cu}$ & $\mathrm{Fe}$ & $\mathrm{Mn}$ & $\mathrm{Zn}$ \\
\hline & $\%$ & $\mathrm{~kg} \mathrm{~kg}$ & & & & & & $\mathrm{~g} \mathrm{~kg}^{-1}$ & & & & $\%$ & & & & & & & & & \\
\hline Astrus Plus ${ }^{1}$ & 6.6 & - & - & 28.3 & 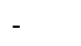 & - & - & - & - & - & - & - & - & 80 & - & - & - & - & - & - & - \\
\hline Astrus Plus ${ }^{2}$ & 7.4 & - & - & 33.6 & - & - & - & - & - & - & - & - & - & 75 & - & - & - & - & - & - & - \\
\hline Astrus Plus ${ }^{3}$ & 6.1 & - & 212.8 & - & - & - & - & - & - & - & - & - & 89 & - & - & - & - & - & - & - & - \\
\hline Astrus Plus ${ }^{4}$ & 6.1 & - & 144.9 & - & - & - & - & - & - & - & - & - & 90 & - & - & - & - & - & - & - & - \\
\hline Astrus Plus ${ }^{5}$ & 6.1 & 30.0 & - & - & 105.8 & 362.9 & 162.1 & 262.8 & 3.6 & 49.5 & - & 76 & 82 & 67 & 24 & 52 & 51 & 42 & 66 & 57 & 84 \\
\hline Astrus Plus ${ }^{6}$ & 5.9 & 40.5 & 184.2 & - & 188.0 & 530.8 & 231.4 & 134.7 & 20.1 & 55.7 & 44.5 & 76 & 80 & 72 & 30 & 54 & 57 & 17 & 55 & 49 & 74 \\
\hline Green Valley $^{7}$ & 6.1 & 34.7 & 155.4 & 18.3 & - & - & 171.8 & 251.1 & 3.9 & 59.9 & 57.8 & 69 & 74 & 68 & - & 63 & 46 & 32 & 47 & 37 & 54 \\
\hline Fenix $^{8}$ & 6.3 & 37.5 & 177.1 & 24.6 & 184.3 & 392.7 & 196.3 & 141.1 & 9.4 & 46.3 & 42.4 & 70 & 76 & 70 & 24 & 45 & 54 & & 52 & 30 & 67 \\
\hline Kenzan $^{9}$ & 7.3 & 33.0 & 303.9 & 27.3 & 102.4 & 447.7 & 162.5 & - & - & - & - & - & - & - & - & - & - & - & - & - & - \\
\hline Kenzan $^{10}$ & 6.5 & 40.8 & 285.7 & 31.3 & 178.6 & 400.0 & 113.9 & - & 17.3 & 48.3 & 50.5 & - & - & - & - & - & - & - & - & - & - \\
\hline Average & 6.5 & 36.1 & 209.1 & 26.1 & 151.8 & 426.8 & 173.0 & 197.4 & 10.9 & 51.9 & 48.8 & 73 & 82 & 72 & 26 & 54 & 52 & 30 & 55 & 43 & 70 \\
\hline SD & 0.5 & 4.3 & 62.6 & 5.5 & 43.7 & 65.6 & 39.2 & 68.9 & 7.6 & 5.7 & 6.9 & 4 & 7 & 5 & 3 & 7 & 5 & 13 & 8 & 12 & 13 \\
\hline$V \max$ & 7.4 & 40.8 & 303.9 & 33.6 & 188.0 & 530.8 & 231.4 & 262.8 & 20.1 & 59.9 & 57.8 & 76 & 90 & 80 & 30 & 63 & 57 & 42 & 66 & 57 & 84 \\
\hline Vmin & 5.9 & 30.0 & 144.9 & 18.2 & 102.4 & 362.9 & 113.9 & 134.7 & 3.6 & 46.3 & 42.4 & 69 & 74 & 67 & 24 & 45 & 46 & 17 & 47 & 30 & 54 \\
\hline $\mathrm{N}^{\circ}$ Data & 10 & 6 & 7 & 8 & 5 & 5 & 6 & 4 & 5 & 5 & 4 & 4 & 6 & 6 & 3 & 4 & 4 & 3 & 4 & 4 & 4 \\
\hline UL & 6.6 & 40.6 & 242.1 & 31.8 & 232.9 & 481.5 & 208.3 & 271.3 & 18.9 & 56.5 & 55.0 & 77 & 88 & 76 & 33 & 61 & 58 & 63 & 62 & 56 & 84 \\
\hline LL & 5.9 & 31.6 & 126.3 & 22.5 & 124.3 & 318.5 & 126.0 & 120.9 & 0.0 & 42.4 & 39.9 & 69 & 74 & 66 & 15 & 45 & 47 & 1 & 45 & 30 & 57 \\
\hline
\end{tabular}

Note. 1 = Average values obtained from research of experiment with doses and sources of $\mathrm{K}$ in cabbage (Subsection 2.2.3) in growing season of summer. 2 = Average values obtained from the research of experiment with doses and sources of $K$ in cabbage (Subsection 2.2.3) in growing season of winter. 3, 4, 5, 6, 7 and $8=$ Average values obtained from the research of Silva (2016); $9=$ Average values obtained from the research of Aquino et al. (2009); $10=$ Average values obtained from the research of Correa et al. (2013). SD = standard deviation. Vmax $=$ maximum value. Vmin $=$ minimum value. $\mathrm{N}^{\mathrm{o}}$ Data $=$ number of data observed. $\mathrm{UL}=$ upper limit, considering a confidence interval of $0.05 . \mathrm{LL}=$ lower limit, considering a confidence interval of $0.05 .-=$ Without data obtaining in the present studies or data excluded by large discrepancy among values.

\subsection{Determination of Recovery Efficiency of N, P and K by Cabbage Crop}

The recovery efficiency (RE) measures the percentage of nutrient recovered by plant from the nutrient applied via fertilizer, and calculated with the following equation (Fageria, 1998):

$$
\mathrm{RE}=\left(\mathrm{Q}_{\mathrm{Ad}}-\mathrm{Q}_{\mathrm{NAd}}\right) / \mathrm{Q}_{\mathrm{Ap}} \times 100
$$

where, $\mathrm{RE}=$ Recovery efficiency by plant of the nutrient applied via fertilizer $(\%)$; $\mathrm{Q}_{\mathrm{Ad}}=$ Amount of the nutrient uptake by plant in the fertilized plot $\left(\mathrm{kg} \mathrm{ha}^{-1}\right) ; \mathrm{Q}_{\mathrm{NAd}}=$ Amount of the nutrient uptake by plant in the non-fertilized plot $\left(\mathrm{kg} \mathrm{ha}^{-1}\right) ; \mathrm{Q}_{\mathrm{Ap}}=$ Amount of nutrient applied in soil $\left(\mathrm{kg} \mathrm{ha}^{-1}\right)$.

\subsection{Modeling of REQ Subsystem}

To estimate the nutritional requirement, the REQ subsystem took into account the crop demand (calculated as a function of productivity) and RE of the nutrient applied. Export (EXP), extraction (EXT) and requirement (REQ) were estimated according to the following equations adapted from Dezordi et al. (2015):

$$
\begin{gathered}
\mathrm{EXP}=(10 \cdot \operatorname{prod} \cdot \mathrm{TMS}) / \mathrm{CUB} \\
\mathrm{EXT}=(100 \cdot \mathrm{EXP}) / \mathrm{HI} \\
\mathrm{REQ}=100 \cdot \mathrm{EXT} \cdot \mathrm{K} /(\mathrm{RE} / 100)
\end{gathered}
$$

where, EXP: export of the nutrient $\left(\mathrm{kg} \mathrm{ha}^{-1}\right)$; prod: expected productivity of cabbage heads $\left(\mathrm{t} \mathrm{ha}^{-1}\right)$; TMS: content of dry matter in the heads (\%); CUB: coefficient of biological utilization of the nutrient in cabbage head $\left(\mathrm{kg} \mathrm{kg} \mathrm{k}^{-1}\right)$; EXT: extraction of the nutrient $\left(\mathrm{kg} \mathrm{ha}^{-1}\right)$; HI: harvest index of the nutrient (\%); REQ: nutrient requirement $(\mathrm{kg}$ $\mathrm{ha}^{-1}$ ); RE: recovery efficiency of the nutrient applied (\%); K: adjustment constant of the nutrient accumulation partition. For $\mathrm{N}=1,095282$, for $\mathrm{P}=1,132624$ and for $\mathrm{K}=1,112715$. Both obtained from experiment of accumulation partition of N, P and $\mathrm{K}$ in cabbage plant (Subsection 2.2.2).

\subsection{Subsystem Supply-SUP}

The subsystem SUP of modeling the recommendation was developed only for N, P and K. To estimate the supply, the SUP considered the nutrients available in soil and crop residue. 


\subsubsection{Supply by Soil}

The results of soil chemical analysis, nutrient recovery efficiency by extractors used in soil chemical analysis, and effective root system depth (PER) of cabbage crop were considered in order to estimate the soil nutrient supply according to the following equation:

$$
\text { SUP } X_{\text {soil }}=\left(X_{\text {analysis }} \cdot P E R\right) /\left(R E_{\text {ext }} \cdot 10\right)
$$

where, SUP $X_{\text {soil }}$ : supply of the nutrient $X$ by soil $\left(\mathrm{kg} \mathrm{ha}^{-1}\right)$; $X_{\text {analysis }}$ : content of the nutrient $X$ in chemical analysis $\left(\mathrm{mg} \mathrm{dm}^{-3}\right)$; PER: effective depth of the root system $(\mathrm{cm})$; $\mathrm{RE}_{\text {ext }}$ : recovery efficiency of the nutrient by extractor $\left(\mathrm{mg} \mathrm{dm}^{-3} / \mathrm{mg} \mathrm{dm}^{-3}\right.$-Table 4$)$.

Table 4. Recovery efficiency of nutrient from soil by extractor $\left(\mathrm{mg} \mathrm{dm}^{-3} / \mathrm{mg} \mathrm{dm}^{-3}\right)$ as function, or not, of remaining phosphorus (P-rem)

\begin{tabular}{llll}
\hline Nutrient & Extractor & Equation & $\mathrm{R}^{2}$ \\
\hline $\mathrm{P}$ & Mehlich-1 & $\mathrm{TR}_{\mathrm{P}}=0.0672821+0.012165^{* *} \mathrm{P}-\mathrm{rem}$ & 0.681 \\
$\mathrm{P}$ & Resina & $\mathrm{TR}_{\mathrm{P}}=0.419^{* * *}$-rem.128099 & 0.694 \\
$\mathrm{~K}$ & Mehlich-1 & $\mathrm{TR}_{\mathrm{K}}=0.8020$ & - \\
$\mathrm{K}$ & Resina & $\mathrm{TR}_{\mathrm{K}}=0.7559$ & - \\
\hline
\end{tabular}

Note. $* * *=$ Significant by $t$ test at $0.1 \%$.** = Significant by $t$ test at $1 \%$. Adapted from Morais (1999), Souza (1999) and Melo (2000) cited by Dezordi et al. (2015). P-rem = Remaining Phosphorus (mg L ${ }^{-1}$ ).

Unlike other fertilizers recommendation systems that consider the PER only at $20 \mathrm{~cm}$ depth; for this model it was considered a PER of $40 \mathrm{~cm}$. This greater depth was adopted by the results obtained in the experiments with $\mathrm{K}$ that demonstrated significant contribution at $20-40 \mathrm{~cm}$ depth of soil (data not presented).

In order to estimate the soil $\mathrm{N}$ supply, it employed the kinetic equation of organic matter mineralization from Brazilian soils described by Carvalho et al. (2006) and developed according to the model proposed by Stanford and Smith (1972):

$$
\text { SUP } \mathrm{N}_{\text {soil }}=\left(0.5 \cdot \mathrm{PER} \cdot \mathrm{d}_{\mathrm{soil}} \cdot \mathrm{OOM}_{\mathrm{soil}} \cdot 1.48\right) \cdot \mathrm{e}^{0.006 \mathrm{t}}
$$

where, SUP $\mathrm{N}_{\text {soil }}$ : supply of $\mathrm{N}$ by soil $\left(\mathrm{kg} \mathrm{ha}^{-1}\right)$; PER: effective depth of roots $(\mathrm{cm})$; $\mathrm{d}_{\text {soil }}$ : Soil density $\left(\mathrm{kg} \mathrm{dm}^{-3}\right)$; $t \mathrm{OM}_{\text {soil }}$ : content of organic matter (dag kg $\left.{ }^{-1}\right)$; $\mathrm{t}$ : crop cycle (days).

\subsubsection{Supply by Crop Residues}

The supply of nutrients by crop residues was estimated by the model proposed by Wieder and Lang (1982), which describes the variation of the nutrient content in the decomposing material as function of the crop cycle.

$$
\begin{gathered}
\text { FR X }_{D}=C_{X} \cdot e^{\left(-k_{0} \cdot t\right)} \\
\text { SUP X } X_{R}=C_{X}-F R X_{D}
\end{gathered}
$$

where, FR $X_{D}$ : remaining fraction of nutrient in the decomposing material after elapsed time $t\left(\mathrm{~kg} \mathrm{ha}^{-1}\right) ; \mathrm{C}_{\mathrm{X}}$ : nutrient content in crop residue $\left(\mathrm{kg} \mathrm{ha}^{-1}\right) ; \mathrm{k}_{0}$ : constant of nutrient decomposition (Table 5); t: crop cycle (days); SUP $\mathrm{X}_{\mathrm{R}}$ : supply of nutrient $\mathrm{X}$ by crop residues $\left(\mathrm{kg} \mathrm{ha}^{-1}\right)$.

The nutrient content in crop residues at the time of crop implantation $\left(C_{X}\right)$ was estimated by product between the amount of dry matter of crop residues in the area and the content of the nutrients in these residues. 
Table 5. Constant of decomposition $\left(\mathrm{k}_{0}\right)$ of dry matter (MS) and macronutrients of the main crops previous to the cultivation

\begin{tabular}{lllll}
\hline \multirow{2}{*}{ Crop } & \multicolumn{4}{c}{$\mathrm{k}_{0}$} \\
\cline { 2 - 5 } & $\mathrm{DM}$ & $\mathrm{N}$ & $\mathrm{P}$ & $\mathrm{K}$ \\
\hline Braquiária $_{\text {Crotalaria spectabilis }^{1}}$ & 0.006 & 0.005 & 0.003 & 0.050 \\
Fodder turnip $^{1}$ & 0.004 & 0.020 & 0.015 & 0.030 \\
Millet $^{1}$ & 0.008 & 0.015 & 0.015 & 0.030 \\
Corn and sorghum $^{2}$ & 0.006 & 0.010 & 0.020 & 0.050 \\
Soybean $^{2}$ & 0.005 & 0.010 & 0.010 & 0.030 \\
Fabaceae $^{\text {Poaceae }}$ & 0.015 & 0.027 & 0.027 & 0.063 \\
General & 0.010 & 0.025 & 0.020 & 0.045 \\
\hline
\end{tabular}

Note. 1 = Constants obtained with management carried out during crop flowering. 2 = Constants obtained with crop residues after grain harvest. Adapted from Padovan et al. (2006), Gama-Rodrigues et al. (2007), and Marcelo et al. (2012) cited by Dezordi et al. (2015).

\section{Results and Discussion}

\subsection{Recovery Efficiency of $N, P$ and $K$ by Cabbage Crop}

The RE of applied nutrient was calculated only for N, P and K due to the scarcity of studies for the other nutrients. In the experiments with doses and sources of $\mathrm{K}$ (Subsection 2.2.3) in cabbage the RE obtained were 128 and 109\% in summer and winter periods, respectively. These high values of RE demonstrate that cabbage plants are very efficient to recover $\mathrm{K}$ from soil when in low $\mathrm{K}$ availability, which present considerable 'luxury consumption' and there may have been non-exchangeable K contribution as demonstrated by Chaves et al. (2015) or exchangeable K below $40 \mathrm{~cm}$ from soil surface to that uptake by cabbage (Manning et al., 2017).

Considering the recommendations of Deus et al. (2015) and Santos et al. (2008) it is necessary to consider the $\mathrm{RE}$ as long as the plant does not recover $100 \%$ of the nutrient applied through fertilizers in order to determine the nutrient requirement of plants. For this version of modeling the recommendation was considered a $90 \%$ of RE. Considering a range of 62 to $100 \%$ of RE for N, a higher RE should be considered in situations of crops in fertile soils, with a larger population of plants and without loss of $\mathrm{N}$ sources by volatilization. For this simulation of modeling the recommendation it was considered a RE of $80 \%$.

For P, the RE was obtained from Silva (2016) study, which studied the RE with P application as broadcasting or localized. The RE range for $\mathrm{P}$ was $30-45 \%$ as broadcasting and $45-60 \%$ as localized application. These RE values allow modeling the recommendation users to choose a certain value depending on the application way of phosphate fertilizer and soil buffering power for $\mathrm{P}$. The RE of $\mathrm{P}$ also varies with type of soil, with higher RE in sandy soils due to lower fixation to mineral colloids in comparison to clayey ones (Santos et al., 2008; Muner et al., 2011; Teixeira et al., 2015). For this version of modeling the recommendation, it was considered a RE of $30 \%$ for $\mathrm{P}$ applied as broadcasting and $45 \%$ for localized application.

\subsection{Fertilizers Recomendations}

The fertilizer recommendation for $\mathrm{N}, \mathrm{P}$ and $\mathrm{K}$ was generated according to the nutritional balance philosophy. Thus, the recommendation consisted of the difference between REQ and SUP. In case of P, modeling the recommendation adopted that even when the soil supply is higher than crop requirement, the $\mathrm{P}$ recommended is not lower than a range of $80-160 \mathrm{~kg} \mathrm{ha}^{-1}$ of $\mathrm{P}_{2} \mathrm{O}_{5}$ due to the higher critical level of $\mathrm{P}$ presented by cabbage in the early stages after transplantation (Silva, 2016). The choice of $\mathrm{P}$ dose should be based on soil types and $\mathrm{P}$ application ways, assigning lower doses to the crops in more sandy soils and/or localized application of $P$.

Farmers may perform fertilization after harvest to restore the original fertility, in order to not impoverish the soil along cultivations. Therefore, the modeling recommends to apply the total exported of the area by crop when SUP is greater than REQ. When SUP is lower than REQ, it is suggested to apply the difference between them during the cycle and export after harvest. The application of the equivalent to the export of nutrients after harvest is important especially for $\mathrm{K}$, which is the most absorbed and exported nutrient. Cabbage is able to increase $\mathrm{K}$ content in the leaves without resulting in increased productivity ('luxury consumption'), which results in soil impoverishment after harvest. 
For other nutrients, the modeling presents only the export and extraction of the crop, without recommending the dose to be applied. Thus, the amounts of $\mathrm{Ca}, \mathrm{Mg}, \mathrm{S}, \mathrm{Cu}, \mathrm{Fe}, \mathrm{Mn}$ and $\mathrm{Zn}$ applied should be estimated by responsible technicians in response to crop export and extracting. This criterion was adopted because it is not know the RE of these elements by cabbage; therefore, it is not possible to determine the requirement of these nutrients by crop.

Regarding $\mathrm{K}$ sources, no difference was found between $\mathrm{KCl}$ and $\mathrm{K}_{2} \mathrm{SO}_{4}$ sources on $\mathrm{K}$ accumulation in cabbage in both field experiments (Subsection 2.2.3) and by Correa et al. (2013). Thus, in modeling disregarded sources in K supply to the cabbage. However, in the study of Correa et al. (2013) the sources influenced the accumulation of $\mathrm{S}$ and, according to these data, a range of CUBs should be considered from 86.8 to 106.9 for $\mathrm{S}$ when the source used is $\mathrm{K}_{2} \mathrm{SO}_{4}$. Other suitable options to provide $\mathrm{S}$ for cabbage would be simple superphosphate $(12 \% \mathrm{~S})$, ammonium sulphate $(24 \% \mathrm{~S})$ and agricultural gypsum $(14 \% \mathrm{~S})$.

\subsection{Aplication of the System}

To compare the recommendations of $\mathrm{N}, \mathrm{P}$ and $\mathrm{K}$, simulations were generated for productivities of $50,80,110$ and $140 \mathrm{t} \mathrm{ha}^{-1}$ of heads. The simulations were performed considering a soil classified as Latossolo Vermelho-Amarelo, whose chemical attributes, at 0 to $20 \mathrm{~cm}$ and 20 to $40 \mathrm{~cm}$ depths, are described in the Table 6.

Table 6. Chemical attributes of soil used in the simulations of fertilizer recommendation by modeling the recommendation of nutrients for cabbage crop

\begin{tabular}{|c|c|c|c|c|c|c|c|c|c|c|c|c|}
\hline Layer & $\mathrm{pH}^{(1)}$ & P-rem & $\mathrm{P}^{(2)}$ & $\mathrm{K}^{+(2)}$ & $\mathrm{S}^{(3)}$ & $\mathrm{Ca}^{2+(4)}$ & $\mathrm{Mg}^{2+(4)}$ & $\mathrm{Al}^{3+(4)}$ & $\mathrm{H}+\mathrm{Al}^{(5)}$ & M.O. & V & M \\
\hline $\mathrm{cm}$ & $\mathrm{H}_{2} \mathrm{O}$ & $\mathrm{mg} \mathrm{L}^{-1}$ & \multicolumn{3}{|c|}{---- $\mathrm{mg} \mathrm{dm}^{-3}$----- } & \multicolumn{4}{|c|}{--o-'---- $\mathrm{cmol}_{\mathrm{c}} \mathrm{dm}^{-3}$} & dag $\mathrm{dm}^{-3}$ & \multicolumn{2}{|c|}{---- \% ----- } \\
\hline $0-20$ & 5.7 & 22.4 & 6.8 & 65.0 & 24.0 & 4.4 & 1.0 & 0.00 & 3.6 & 3.1 & 60.7 & 0.0 \\
\hline $20-40$ & 5.7 & 14.3 & 2.2 & 34.0 & 23.0 & 3.6 & 0.9 & 0.00 & 3.5 & 2.5 & 56.7 & 0.0 \\
\hline
\end{tabular}

Note. $(1)=$ Ratio 1:2.5. (2) = Mehlich 1 extractor. $(3)=$ monocalcium phosphate extractor in acetic acid. (4) $=$ $\mathrm{KCl} 1 \mathrm{~mol} \mathrm{~L}^{-1}$ extractor. $(5)=$ calcium acetate extractor $0.5 \mathrm{~mol} \mathrm{~L}^{-1} / \mathrm{pH} 7.0$.

It was also considered in fields cultivation the existence of $8 \mathrm{tha}^{-1}$ of crop residues of maize (vegetative dry matter - leaves and stems) with $8.11 ; 0.52 ; 21.82 \mathrm{~g} \mathrm{~kg}^{-1}$ of N, P and K in DM, respectively (Setiyono et al., 2010). For calculation purposes, it was considered that cabbage presented 75 days of cycle after seedlings transplanting to the cultivation place, and $40 \mathrm{~cm}$ was adopted as PER of the crop.

\subsection{Simulation of Modeling the Recommendation of Nutrients for Cabbage Crop}

The simulations performed by modeling showed that the expected productivity influences the nutrients export (quantity accumulated in heads) and extraction (amount accumulated in the heads and external leaves) (Table 7). Potassium was the most exported and extracted macronutrient, followed in decreasing order by N, Ca, S and P. For micronutrients, $\mathrm{Fe}$ was the most absorbed, followed in decreasing order by $\mathrm{Zn}, \mathrm{Mn}$ and $\mathrm{Cu}$. 
Table 7. Export and extraction of macro and micronutrients generated by modeling the recommendation of nutrients for cabbage crop in response to the expected productivity

\begin{tabular}{|c|c|c|c|c|c|c|c|c|}
\hline \multirow{3}{*}{ Nutrient } & \multicolumn{8}{|c|}{ Expected productivity $\left(\mathrm{t} \mathrm{ha}^{-1}\right)$} \\
\hline & \multicolumn{4}{|c|}{ Export } & \multicolumn{4}{|c|}{ Extraction } \\
\hline & 50 & 80 & 110 & 140 & 50 & 80 & 110 & 140 \\
\hline & \multicolumn{8}{|c|}{ 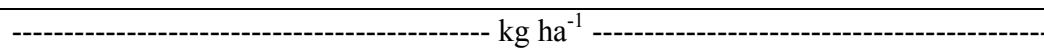 } \\
\hline $\mathrm{N}$ & 89 & 143 & 197 & 250 & 123 & 197 & 270 & 344 \\
\hline $\mathrm{P}$ & 15 & 25 & 34 & 43 & 19 & 30 & 41 & 53 \\
\hline $\mathrm{K}$ & 124 & 198 & 272 & 346 & 172 & 275 & 378 & 481 \\
\hline $\mathrm{Ca}$ & 21 & 34 & 47 & 60 & 82 & 131 & 180 & 229 \\
\hline $\mathrm{Mg}$ & 8 & 12 & 17 & 21 & 14 & 23 & 31 & 40 \\
\hline \multirow[t]{2}{*}{$\mathrm{S}$} & 19 & 30 & 41 & 52 & 36 & 57 & 79 & 100 \\
\hline & \multicolumn{4}{|l|}{$\mathrm{g} \mathrm{ha}^{-1}$} & \multicolumn{4}{|c|}{$\mathrm{g} \mathrm{ha}^{-1}$} \\
\hline $\mathrm{Cu}$ & 16 & 26 & 36 & 46 & 54 & 86 & 119 & 151 \\
\hline $\mathrm{Fe}$ & 297 & 474 & 652 & 830 & 539 & 863 & 1186 & 1510 \\
\hline $\mathrm{Mn}$ & 62 & 99 & 137 & 174 & 144 & 230 & 316 & 402 \\
\hline $\mathrm{Zn}$ & 66 & 106 & 146 & 185 & 95 & 152 & 209 & 266 \\
\hline
\end{tabular}

Note. Export = quantity accumulated of macro and micronutrients in heads. Extraction $=$ amount accumulated of macro and micronutrients in the heads and external leaves.

For the macronutrients $\mathrm{Ca}, \mathrm{Mg}$ and $\mathrm{S}$ and micronutrients $\mathrm{Cu}, \mathrm{Fe}, \mathrm{Mn}$ and $\mathrm{Zn}$, the modeling showed only export and extraction of the crop for simulations performed (Table 7). Due to the lack of knowledge about RE of these nutrients, it was not possible to estimate REQ subsystem therefore, to generate fertilizers recommendation. It reinforces the need to carry out studies with other nutrients to the complete the modeling.

From the results of the experiment to determine the nutrient accumulation in whole cabbage plant (Subsection 2.2.2), it was possible to determine the constants to fit in the requirements of $\mathrm{N}, \mathrm{P}$ and $\mathrm{K}$. Without constants use, the requirements values of $\mathrm{N}, \mathrm{P}$ (furrow and broadcasted) and $\mathrm{K}$ for a yield of $140 \mathrm{t} \mathrm{ha} \mathrm{a}^{-1}$ were 430, 117,176 and $535 \mathrm{~kg} \mathrm{ha}^{-1}$ of N, P and K, respectively, whereas with the constants uses these values were 471, 133, 200 and 595 $\mathrm{kg} \mathrm{ha}^{-1}$ of $\mathrm{N}, \mathrm{P}$ and $\mathrm{K}$, respectively. Constants demonstrate the need to model a recommendation system that considers beyond the nutrient accumulation in the plant shoot, the nutrients allocated in the root system.

The modeling the recommendation simulated the crop requirement from average values, but since there is a range of values (Table 3), the system has flexibility that allows the user a choice based on their growing conditions. In addition, the system allows constant updates from new studies that generate results consistent with the reality of the crops in the field, such as the knowledge of nutrients CUB to determine cultivar and cultivation condition.

In the simulations generated by modeling, the supply of $\mathrm{Ca}$ and $\mathrm{Mg}$ via liming, and $\mathrm{Ca}$ and $\mathrm{S}$ via gypsum were not considered because the application of these correctives was unnecessary, based on chemical analysis used in the simulation (Table 6). The recommendation modeling requires the application by the crop and this was only calculated for N, P and K, since only for these nutrients it was possible to determine the RE. Gypsum application should be carried out on soils with high levels of $\mathrm{Al}^{3+}$ in subsurface and when fertilizers containing $\mathrm{S}$ are not applied during cabbage cultivation, aiming this nutrient supply.

Fertilizer recommendation should be generated in order to avoid soil impoverishment along cultivations. In high fertility conditions, the soil nutrient supply is high and may be higher than crop requirement, as observed for $\mathrm{P}_{2} \mathrm{O}_{5}$ recommendations (localized) at yield of $50 \mathrm{t} \mathrm{ha}^{-1}$, and $\mathrm{K}_{2} \mathrm{O}$ at $80 \mathrm{t} \mathrm{ha}^{-1}$ (Table 8). 
Table 8. Recommendations of $\mathrm{N}, \mathrm{P}_{2} \mathrm{O}_{5}$ (with application of $\mathrm{P}$ localized and broadcasting) and $\mathrm{K}_{2} \mathrm{O}$, generated by modeling the recommendation of nutrients and by literature for different expected productivities for cabbage crop

\begin{tabular}{|c|c|c|c|c|c|c|}
\hline \multirow{2}{*}{ Nutrient } & & \multicolumn{4}{|c|}{ Expected productivities $\left(\mathrm{t} \mathrm{ha}^{-1}\right)$} & \multirow{2}{*}{$\begin{array}{l}\text { CFSEMG (1999)* } \\
50\left(\mathrm{t} \mathrm{ha}^{-1}\right)\end{array}$} \\
\hline & & 50 & 80 & 110 & 140 & \\
\hline$\overline{\mathrm{N}}$ & & $0^{1}$ & 72 & 173 & 274 & 150 \\
\hline $\mathrm{P}_{2} \mathrm{O}_{5}$ & Localized & $80^{2}$ & $80^{2}$ & 109 & 174 & - \\
\hline $\mathrm{P}_{2} \mathrm{O}_{5}$ & Broadcasting & $160^{3}$ & $160^{3}$ & 229 & 327 & 400 \\
\hline $\mathrm{K}_{2} \mathrm{O}$ & & $0^{1}$ & $0^{1}$ & 55 & 209 & 180 \\
\hline
\end{tabular}

Note. ${ }^{*}=$ Values obtained from literature considering soil analysis (Table 6) with low $\mathrm{P}$ availability and average availability of K. 1 = Without fertilizer recommendation during cultivation. $2=$ Recommendation of $80 \mathrm{~kg} \mathrm{ha}^{-1}$ of $\mathrm{P}_{2} \mathrm{O}_{5}$ as starting of P. $3=$ Recommendation of $160 \mathrm{~kg} \mathrm{ha}^{-1}$ of $\mathrm{P}_{2} \mathrm{O}_{5}$ as starting of $\mathrm{P}$.

For $\mathrm{P}$, in high fertility soils, it is necessary to apply at least $80 \mathrm{~kg} \mathrm{ha}^{-1}$ of $\mathrm{P}_{2} \mathrm{O}_{5}$ (localized), and up to $160 \mathrm{~kg}^{-1}$ of $\mathrm{P}_{2} \mathrm{O}_{5}$ (broadcasting). Considering the soil analysis used in this simulation, in lowest yields the availability of $\mathrm{P}$ was considered high and, in this case, it may apply $80 \mathrm{~kg} \mathrm{ha}^{-1}$ of $\mathrm{P}_{2} \mathrm{O}_{5}$ (localized) and $160 \mathrm{~kg} \mathrm{ha}^{-1}$ of $\mathrm{P}_{2} \mathrm{O}_{5}$ (broadcasting). For higher yields, the soil presents supply of $\mathrm{P}$ below cabbage requirement; the dose applied is the difference between the requirement and supply.

For $\mathrm{N}$, at productivity of $50 \mathrm{t} \mathrm{ha}^{-1}$, and $\mathrm{K}$ at productivities of 50 and $80 \mathrm{t} \mathrm{ha}^{-1}$, where the soil supply was higher than plant requirement, it was not recommended to apply them. Therefore, fertilization is recommended after cultivation in order to preserve soil fertility. These fertilizations should be based on crop export values.

The nutrient doses recommended in the literature are different from those of modeling (Table 8). For cabbage fertilization, only range of nutrient availability in the soil is considered, without considering the expected productivity or effect of previous crop CFSEMG (1999).

In case of $\mathrm{N}$, the dose recommended by CFSEMG (1999) is $150 \mathrm{~kg} \mathrm{ha}^{-1}$. It is not considered the organic matter content or contribution of crop residues. The recommendations of $\mathrm{P}_{2} \mathrm{O}_{5}$ and $\mathrm{K}_{2} \mathrm{O}$ are 400 and $180 \mathrm{~kg} \mathrm{ha}{ }^{-1}$, respectively, which is higher than those generated by modeling in order to reach a yield of $50 \mathrm{t} \mathrm{ha}^{-1}$.

\section{Conclusions}

The modeling the recommendation of nutrients for cabbage crop is a useful tool to recommend fertilizers for cabbage crop with an advantage that recommendations vary with expected productivity and nutrient content available in the soil and crop residues of previous crops.

The system has great prospects in order to optimize the use of fertilizers in cabbage crop. However, it requires more specific information for its improvement, such as studies about recovery efficiency of $\mathrm{Ca}, \mathrm{Mg}, \mathrm{S}$ and micronutrients.

\section{References}

Aquino, L. A., Puatti, M., Lelis, M. M., Pereira, P. R. G., \& Pereira, F. H. F. (2009). Produção de biomassa, teor e exportação de macronutrientes em plantas de repolho em função de doses de nitrogênio e de espaçamentos. Ciência e Agrotecnologia, 33, 1295-1300. https://doi.org/10.1590/S1413-70542009000500014

Carvalho, F. T., Novais, R. F., Alvarez, V. V. H., Barros, N. F., Cantarutti, R. B., \& Bahia Filho, A. F. C. (2006). Sistema de interpretação de análise de solo para recomendação de NPK para a cultura do milho. Revista Ceres, 53, 211-223.

CFSEMG (Comissão de Fertilidade do Solo do Estado de Minas Gerais). (1999). Recomendações para o uso de corretivos e fertilizantes em Minas Gerais (5th ed., p. 359). Viçosa, Brazil.

Chaves, E, Pedron F. A., Melo, V. F., \& Dalmolin, R. S. D. (2015). Reserva mineral de K por diferentes métodos em argissolos subtropicais. Revista Brasileira de Ciência do Solo, 39, 1088-1099. https://doi.org/10.1590/ 01000683 rbcs 20140670

Correa, C. V., Cardoso, A. I. I., \& Claudio, M. D. T. R. (2013). Produção de repolho em função de doses e fontes de potássio em cobertura. Semina: Ciências Agrárias, 34, 2129-2138. https://doi.org/10.5433/1679-0359. $2013 v 34 n 5 p 2129$ 
Deus, J. A. L., Soares, I., Neves, J. C. L., Medeiros, J. F., \& Miranda, F. R. (2015). Fertilizer recommendation system for melon based on nutritional balance. Revista Brasileira de Ciência do Solo, 39, 498-511. https://doi.org/10.1590/01000683rbcs20140172

Dezordi, L. R., Aquino, L. A., Novais, R. F., Aquino, P. M., \& Santos, L. P. D. (2015). Nutrient recommendation model for carrot crop-Ferticalc Carrot. Revista Brasileira de Ciência do Solo, 39, 1714:22.

Fageria, N. K. (1998.) Otimização da eficiência nutricional da produção das culturas. Revista Brasileira de Engenharia Agrícola e Ambiental, 2, 6-16. https://doi.org/10.1590/1807-1929/agriambi.v02n01p6-16

Kurihara, C. H., Alvarez, V. V. H., Neves, J. C. L., \& Novais, R. F. (2013). Acúmulo de matéria seca e nutrientes em soja, como variável do potencial produtivo. Revista Ceres, 60, 690-698. https://doi.org/10.1590/S0034737X2013000500013

Manning, D. A. C., Baptista, J., Limon, M. S., \& Brandt, K. (2017). Testing the ability of plants to access potassium from framework silicate minerals. Science of the Total Environment, 574, 476-481. https://doi.org/10.1016/j.scitotenv.2016.09.086

Marcelo, A. V., Corá, J. E., \& Fernandes, C. (2012). Sequências de culturas em sistema de semeadura direta. II-Decomposição e liberação de nutrientes na entressafra. Revista Brasileira de Ciência do Solo, 36, 1568-1582. https://doi.org/10.1590/S0100-06832012000500021

Muner, L. H., Ruiz, H. A. Venegas, V. H. A., Neves, J. C. L., Freire, F. J., \& Freire, M. B. G. S. (2011). Disponibilidade de zinco para milho em reposta à localização de fósforo no solo. Revista Brasileira de Engenharia Agrícola e Ambiental, 15, 29-36. https://doi.org/10.1590/S1415-43662011000100005

Raij, B. Van, Cantarella, H., Quaggio, J. A., \& Furlani, A. M. C. (1996.) Recomendações de adubação e calagem para o estado de São Paulo (2nd ed., pp. 60-61). Campinas, Instituto Agronômico de Campinas.

Santos, F. C., Neves, J. C. L., Novais, R. F., Alvarez, V. V. H., \& Sediyama, C. S. (2008). Modelagem da recomendação de corretivos e fertilizantes para a cultura da soja. Revista Brasileira de Ciência do Solo, 32 , 1661-1674. https://doi.org/10.1590/S0100-06832008000400031

Setiyono, T. D., Walters, D. T., Cassman, K. G., Witt, C., \& Dobermann, A. (2010). Estimating maize nutrient uptake requirements. Field Crops Research, 118, 158-168. https://doi.org/10.1016/j.fcr.2010.05.006

Silva, A. P., Alvarez, V. V. H., Souza, A. P., Neves, J. C. L., Novais, R. F., \& Dantas, J. P. (2009). Sistema de recomendação de fertilizantes e corretivos para a cultura do abacaxi-FERTICALC-Abacaxi. Revista Brasileira de Ciência do Solo, 33, 1269-1280. https://doi.org/10.1590/S0100-06832009000500020

Silva, F. C. (2009). Manual de análises químicas de solos, plantas e fertilizantes (2nd ed., p. 627). Brasília, DF: Embrapa Informação Tecnológica.

Silva, L. O. D. (2016). Influência de doses e modos de aplicação de fósforo e determinação da curva de acúmulo de nutrientes na cultura do repolho (Unpublished Master's Thesis, Federal University of Viçosa-Campus Rio Paranaíba, Rio Paranaíba, Brazil).

Singh, D. P., Beloy, J., Mcinerney, J. K., \& Day, L. (2012). Impact of boron, calcium and genetic factors on vitamin C, carotenoids, phenolic acids, anthocyanins and antioxidant capacity of carrots (Daucus carota L.). Food Chemistry, 132, 1161-1170. https://doi.org/10.1016/j.foodchem.2011.11.045

Stanford, G. S., \& Smith, S. J. (1972). Nitrogen mineralization potentials of soils. Soil Science Society of America Journal, 36, 465-72. https://doi.org/10.2136/sssaj1972.03615995003600030029x

Teixeira, P. C., Mesquita, I. L., Macedo, S. T., Teixeira, W. G., \& Lima, W. A. A. (2015) Resposta de vetiver à aplicação de calcário e fósforo em três classes de solo. Revista Brasileira de Engenharia Agrícola e Ambiental, 19, 99-105. https://doi.org/10.1590/1807-1929/agriambi.v19n2p99-105

Wieder, R. K., \& Lang, G. E. (1982). A critique of the analytical methods used in examining decomposition data obtained from litter bags. Ecology, 63, 1636-1642. https://doi.org/10.2307/1940104

\section{Copyrights}

Copyright for this article is retained by the author(s), with first publication rights granted to the journal.

This is an open-access article distributed under the terms and conditions of the Creative Commons Attribution license (http://creativecommons.org/licenses/by/4.0/). 